\title{
Geomorphology of Mandvi to Mundra Coast, Kachchh, Western India
}

\author{
Heman V. Majethiya, Nishith Y. Bhatt and Paras M. Solanki \\ Geology Department, M.G. Science Institute, Navrangpura, Ahmedabad - 380009. India \\ Email: heman16@gmail.com
}

\begin{abstract}
Landforms of coast between Mandvi and Mundra in Kachchh and their origin are described here. Various micro-geomorphic features such as delta, beaches (ridge \& runnel), coastal dunes, tidal flat, tidal creek, mangrove, backwater, river estuary, bar, spit, saltpan etc. are explained. The delta sediment of Phot River is superimposed by tidal flat sediments deposited later during uplift in last 2000 years. Raise-beach, raise-tidal flat, firm sub-tidal mud pockets on beach, delta and parabolic dune remnants and palaeo-fore dune (Mundra dune) - all these features projects 3 to $4 \mathrm{~m}$ high palaeo-sea level than the present day. All these features are superimposed by present day active beach, dune, tidal flat, creek, spit, bar, lagoon, estuary and mangroves. All these are depositional features.
\end{abstract}

Keywords: Coastal Geomorphology, mandvi, mundra, kachchh, landforms.

\section{Introduction}

The micro-geomorphic features, their distribution and origin in Mandvi to Mundra segment of Kachchh are described here. Tides, waves and currents are common coastal processes responsible for erosion, transportation and deposition of the sediments and produce erosional and depositional landform features in the study area.

Tides are the rise and fall of sea levels caused by the combined effects of the gravitational forces exerted by the Moon and the Sun and the rotation of the Earth. Most places in the ocean usually experience two high tides and two low tides each day (semi-diurnal tide), but some locations experience only one high and one low tide each day (diurnal tide). The times and amplitude of the tides at a locale are influenced by the alignment of the Sun and Moon, by the pattern of tides in the deep ocean and by the shape of the coastline and near-shore bathymetry. The study area is affected by semi-diurnal tidal cycles. Almost half of the study area is tide dominated. While tides are usually the largest source of short-term sea-level fluctuations, sea levels are also subject to forces such as wind and barometric pressure changes, resulting in storm surges, especially in shallow seas and near coasts.

Wind waves or, more precisely, wind-generated waves are surface waves that occur on the free surface of seas and oceans. They usually result from the wind blowing over a vast enough stretch of fluid surface. Wind waves range in size from small ripples to huge waves over 30 meters high. Wind waves in the ocean are called ocean surface waves. As waves travel from deep to shallow water, their shape alters (wave height increases, speed decreases, and length decreases as wave orbits become asymmetrical). This process is called shoaling. The great majority of large breakers one observes on a beach result from distant winds. Five factors influence the formation of wind waves which work together to determine their size: 1. Wind speed, 2. Distance of open water that the wind has blown over (called the fetch), 3. Width of area affected by fetches, 4. Time duration the wind has blown over a given area, 5. Water depth.

Some waves undergo a phenomenon called "breaking". A breaking wave is one whose base can no longer support its top, causing it to collapse, when it runs into shallow water. Such wave related processes are visible in the study area.

An ocean current is a continuous, directed movement of ocean water generated by the forces acting upon this mean flow, such as breaking waves, wind, Coriolis effect, cabbeling, temperature and salinity differences and tides caused by the gravitational pull of the Moon and the Sun. Depth contours, 
shoreline configurations and interaction with other currents influence a current's direction and strength. Ocean currents can flow for great distances.

Long shore drift consists of the transportation of sediments (generally sand but may also consist of coarser sediments such as gravels) by long shore currents along a coast at an angle to the shoreline, which is dependent on prevailing wind direction, tidal currents, swash and backwash. This process, which is also known as long-shore transport or littoral drift, occurs in the intertidal zone, and in or within close proximity to the surf zone, can generate oblique breaking waves which result in long-shore transport. If there is a slight change of sediment supply, wind direction, or any other coastal influence long-shore drift can change dramatically, impacting on the formation and evolution of a beach system or profile. Some of these are geological changes, e.g. erosion, backshore changes and emergence of headlands.

Wave and tide generated currents are distinctly affecting study area.

Table 1. Details of segments, sub-segments, coast type and micro-geomorphic features (modified after [14]).

\begin{tabular}{llll}
\hline Segment & Sub-segment & Coast type & Micro-geomorphic features \\
\hline Mandvi to Mundra (spits & Mandvi to & Mixed coast & Beaches (ridge \& runnel), coastal dunes, tidal \\
and cuspate foreland & Mundra & & flat, tidal creek, mangrove, backwater, river \\
complex) & & estuary, bar, spit, saltpan. \\
\hline
\end{tabular}

\section{Landforms of Depositional Coasts - Mandvi to Mundra (Spits and Cuspate Foreland Complex) Segment}

Depositional coasts may experience erosion at certain times and places due to factors such as storms, depletion of sediment supply, and rising sea level. The overall, long-range tendency along these coasts is that of sediment deposition. Kachchh coast line, specifically Mandvi to Mundra segment, mainly shows characteristics of such a depositional coast. When wave, tide and current energy is less due to dissipation on low gradient bottom and sediment supply is moderate to high from tides and rivers, which is not completely carried away by marine processes, depositional landforms are originated.

Waves, wave-generated currents, and tides are the processes evident along depositional coast, which significantly influence the development of depositional landforms. The landforms that develop along some coasts are due primarily to wave processes while along other coasts they may be due mainly to tidal processes. Some coasts are the result of near equal balance between tide and wave processes. As a consequence, investigators speak of wave-dominated coasts, tide-dominated coasts, and mixed coasts.

A wave-dominated coast is one that is characterized by well-developed sand beaches typically formed on long barrier islands with a few widely spaced tidal inlets. The barrier islands tend to be narrow and rather low in elevation. Long shore transport is extensive, and the inlets are often small and unstable.

A Tide-dominated coast is not as widespread as those dominated by waves. They tend to develop where tidal range is high or where wave energy is low. The result is a coastal morphology that is dominated by funnel-shaped embayment and long sediment bodies oriented essentially perpendicular to the overall coastal trend. Tidal flats, salt marshes, and tidal creeks are extensive.

Mixed coasts are those where both tidal and wave processes exert considerable influence. These coasts characteristically have short stubby barrier islands and numerous tidal inlets. The barriers commonly are wide at one end and narrow at the other. Inlets are fairly stable and have large sediment bodies on both their landward and seaward sides.

On Mandvi to Mundra segment, towards west near Mandvi coast is wave dominated; while towards east near Mundra it is tide dominated and in-between coast is of mix type. The Mandvi to Mundra segment runs for about $40 \mathrm{~km}$ and characterized by both sandy and muddy landforms like Beaches (ridge and runnel), coastal dunes, tidal flat, bar, salt pan, backwater, creek and mangrove (Fig. 1). 


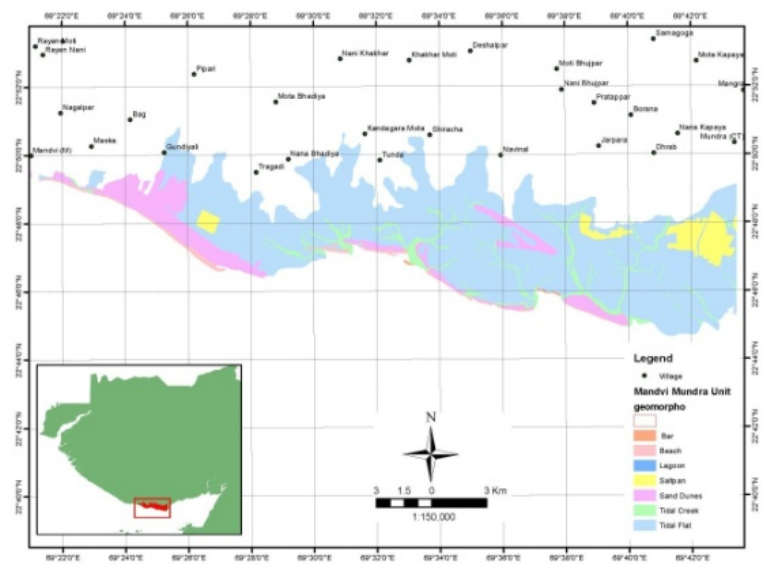

Figure 1. Micro-geomorphic features of Mandvi to Mundra segment.

Following is a generalized account of landforms occurring in the study area.

\subsection{In Shore Crescentic Barrier Beaches-Bars}

Barrier Beaches are dynamic strips of coastal dunes and beaches that are formed by long shore currents depositing sand across the mouth of an inlet or harbor. Barrier beaches are divided into frontal beach, dune, and inland beach, usually with a marsh or estuary system in the sheltered zone behind the barrier.

These beaches are dynamic systems that are constantly subjected to wind and wave energy. Vegetated areas on the barrier are stable, but sandy areas migrate and large storms can rip holes right through the barrier. Inland areas are buffered by the barrier beaches, which dissipate storm wave energy by their shifting sands. Beaches are resulted from wave action due to waves or currents which move sand by suspension, saltation or traction. Beach materials come from erosion of offshore rocks, from headland erosion, long shore-currents, nearby rivers and slumping producing deposits of scree. Constructive waves move material up the beach while destructive waves move the material down the beach. On sandy beaches, the backwash of the waves removes material forming a gently sloping beach. On shingle beaches the swash is dissipated because the large particle size allows percolation, so the backwash is not very powerful, and the beach remains steep. On Mandvi, Modava and Navinal coast, beaches are mainly sandy but partly made up of shingles. Cusps and horns form where incoming waves divide, depositing sand as horns and scouring out sand to form cusps.

Barrier Islands are relatively narrow strips of sand that are parallel/sub-parallel to the mainland coast of Modava, and Navinal, cut by tidal inlets. The length and width of barriers and overall morphology of barrier coasts are related to parameters like tidal range, wave energy, sediment supply, sea-level trends and basement controls.

Bars are sand ridges below low tide level. Seven bars are observed in the segment. Three bars occur on the west of Mundra Port, two near mouth of Bharadi Mata creek and two near old Mundra Port. Total area of the bar is $19.3 \mathrm{Ha}$ (Plate 1e, c).

\subsubsection{Beaches}

There are several specific landforms representative of coastal environments that are common to each of the three major categories: wave dominated coast, tide dominated coast and mix coast described above. Beaches are prominent among them, which are primary landforms on barrier islands, strand-plain coasts, and many deltas, particularly the wave-dominated variety.

The near shore environment extends from the outer limit of the long shore bars that are usually present to the low-tide line. The beach extends from the low-tide line to the distinct change in slope and/or material landward of the un-vegetated and active zone of sediment accumulation. It may consist of sand, gravel, or even mud, though sand is the most common beach material.

The beach profile typically can be divided into two distinct parts:

(1) The seaward and relatively steep sloping foreshore, which is essentially the intertidal beach, and 
(2) The landward, nearly horizontal backshore.

During quiescent wave conditions, the beach is said to be accretional, and both the foreshore and backshore are present. During storms the waves tend to be steep, and erosion of the beach occurs with sediment transported offshore, forming a profile that shows only the seaward sloping foreshore. The intervening calmer conditions permit sediment to be transported landward and rebuild the beach itself during non-storm periods; a cyclic pattern of profile shapes is common. This is the most active zone of continual change. During non-storm conditions the back-beach is relatively inactive except for wind action, which may move sediment.

There are variations in beach forms along - parallel - and across - perpendicular - to the shore. The most common is the rhythmic topography - undulating surface that is seen along the foreshore, which is seen both on the plan view and the topography. The elevated portions -swells - are ridges, while depressions or sinuses form runnels.

Beach formation has occurred all along the coast for a distance of about $40 \mathrm{~km}$ from Mandvi to mouth of Bhukhi River near Mundra. The beach is sandy and steeper with slope of $10^{\circ}$ to $15^{\circ}$. The maximum width during low tide level is $150 \mathrm{~m}$ on Mandvi (Kashi Vishwanath) beach. The beach is developed on the outermost coast covering tidal flats on its back. This beach shows both ridges and runnel topography. The beach covers an area of $281.5 \mathrm{Ha}$ (Plate 1a, 2a).

\section{$2.2 \quad$ Coastal Dunes}

Dunes are the representatives of coastal environments that are common to wave dominated, tide dominated and mix coast. They are the primary landforms on barrier islands, strand-plain coasts, and wave-dominated delta.

Immediately landward of the beach are large, linear sand deposits known as dunes. They form wherever an obstruction hinders further transport of sand. In most cases the dunes are important in protecting the land against potential ravages by storm waves from the sea.

Dunes may form on the backshore of the beach as fine to medium, well sorted sand accumulations. Various types of vegetation grow on the dune surface and stabilize it. Dunes lacking vegetation are active and exhibit various signs of sand mobility. Most widespread are the ripples that cover the dune surface. Large lobes of sand or an entire dune may move as wind blows. This activity results in crossstratification of the dune in large sweeping patterns of wedge-shaped packages of sand. In the study area two types of dunes are recognized e.g. fore-dune and parabolic dune.

The seaward-most line of shore-parallel, coastal dune ridges is fore-dune. It forms on the top of the backshore by aeolian sand deposition. They form as wind carries sediment from beach in a landward direction and deposit it wherever obstruction hinders further transport. Sediment supply is a key limiting factor in dune development.

Coastal areas may have dunes running parallel to each other inland from the beach. U-shaped mounds of sand with convex noses trailed by elongated arms are parabolic dunes. They can originate from beach sands and extend inland into vegetated areas in coastal zones. Parabolic dunes, like crescent dunes, occur in areas where very strong unidirectional, consistent winds blow. Parabolic dunes are dependent on the vegetation which helps anchor the trailing arms and held it in place. Sometimes these dunes are called U-shaped, blowout, or hairpin dunes, from the shape in plan-view and they are well known in coastal deserts. Their crests point upwind. There slip faces occur on the outer side of the nose and on the outer slopes of the arms. Most parabolic dunes do not reach heights higher than a few tens of meters except at their nose, where vegetation stops or slows the advance of accumulating sand.

The grain size for these well-sorted, very fine to medium sands is about 0.06 to $0.5 \mathrm{~mm}$. Parabolic dunes have unconsolidated sand and steep slopes only on their outer flanks. Nose and trailing arms is without vegetation. The inner slopes and corridors between individual dunes are mostly well vegetated.

In this segment, the fore-dune development is present on beaches having width of 700-800 $\mathrm{m}$ and maximum length of $6 \mathrm{~km}$ having height of $\sim 10 \mathrm{~m}$. Fore-dunes are covered by vegetation. Such dunes are mainly made up of fine well sorted sands. The Sand Dunes cover an area of 1954.8 Ha (Plate 1d, e). Parabolic dunes are also present on Navinal coast at the base of New Mundra port as dunes of earlier phase. 


\section{$2.3 \quad$ Tidal Flats}

Mudflats or mud flats, also known as tidal flats, are coastal wetlands that form when mud is deposited by tides or rivers. They are found in sheltered areas such as bays, bayous, lagoons and estuaries. Most of the sediment within a mudflat is within the intertidal zone, and thus the flat is submerged and exposed twice daily. It can also be formed by deposition in the protected areas behind barrier or spit etc. Distal part of delta in the intertidal zone may also produce vast tidal mud flats. Here, mud may reach up to $40 \%$ of the sediment, and the remaining part may be constituted by silt and fine sand. Energy level of wave, tides and current is low and fine sediment supply is high in such cases. Such tidal mud flats are present in the study area.

Sedimentary intertidal habitats created by deposition in low energy coastal environments, particularly estuaries and other sheltered areas, can be defined as sand flat. Sediments generally consist of sand with silts and clays containing a high organic content. Active deposition of sand occurs over silt and mud. In arid to semi-arid regions, high rate of evaporation deposits salt when area becomes semi-dry. Such low gradient intertidal areas covered with sand and salt can be termed as saline sand flats. Similar saline sand flats are present in the area.

The Mnadvi to Mundra coast is characterized by narrow to vast tidal flats in inter tidal zone in between high tide level to low tide level. Width of tidal flats reaches up to $6 \mathrm{~km}$ in the study area and length up to $15 \mathrm{~km}$ south of Wandh and Navinal villages where tidal flats are formed behind barriers by filling up shallow lagoons and marshes. Slope of the area is very less, generally $2^{\circ}$ to $3^{\circ}$; on which wave and tide energy dissipate to give rise to deposition of finer particles in calm conditions to form vast tidal flats. Such areas are traversed by seven barrier islands, four bars and two spits, forming protected condition leading to decrease in wave, tide and resulting current energy and hence deposition of finer particles. Tidal flats are commonly cut across by tidal creeks. Tidal flats are extensively developed. The tidal flat covers an area of $12888.6 \mathrm{Ha}$ (Plate 1a, e).

\subsection{Tidal Creek}

A tidal creek is a tidal water channel that is affected by ebb and flood tides of sea or ocean. It discharges to ocean, sea or strait. It has variable salinity and electrical conductivity over the tidal cycle. Due to the temporal variability of water quality parameters within the tidally influenced zone, there are unique biota associated with tidal creeks, which are often specialized to such zones. Creeks may often dry to a muddy channel with little or no flow at low tide, but often with significant depth of water at high tide.

In Kachchh, the term also applies to the salt water inlets from the sea enclosed by mangroves. Creeks are found dispersed all along the Indian coast. There are nine tidal creeks found along this segment. Tidal creeks are radially arranged in NW, N and NE respectively from the Gulf of Kachchh. One creek found near Raval Pir, second at the end of Modava spit, third near Vandh, two channels of Kotadi creek are present near Navinal village, Bharadi Mata creek is present near Bharadi Mata temple on Mundra dune, and three creeks are present near Mundra port. The tidal creek covers an area of 1149.9 Ha (Plate 1b, d, e and 3c).

\subsection{Saltpan}

One cluster of salt pan is seen on the back side of Modava spit, while another cluster of salt pan is observed around Navinal port in tidal flat areas. The salt pan covers an area of $824.4 \mathrm{Ha}$ (Plate 1b, d).

\subsection{Mangroves}

The coastal wetland of the Kachchh district with numerous creeks and channels associated with shoals and vast tidal flats have one of the richest mangroves along the west coast of India. Hence, a portion of the mangroves of the Kachchh region are classified under the "West Mangrove Reserve Forest". The area covered by mangroves on Kachchh coast line is estimated based on satellite data which is about $938 \mathrm{~km}^{2}$ in 1998 which has considerably increased from 1992 onwards. Majority of its mangroves are scrubby and of low height. 
Avicenna marina is the dominant species, which constitutes over $95 \%$ of total mangrove trees in Gujarat. The common mangrove family is Rhizophoraceae, mangrove trees belongs to genus Rhizophora. Mangroves function as stabilizer of sediment on shoreline and protect coast from storm and salty wind. Over $90 \%$ of mangroves of Gujarat occur along the coastline of Gulf of Kachchh. In the past, Gulf of Kachchh had extensive mangrove cover along coast, but they were destroyed as a result of cutting, lopping and camel grazing. However some areas in Jamnagar and Kori creek of Kachchh faced loss of mangroves as result of cyclones that occurred in the year 1998 and 1999 [16].

Mangroves are present on the tidal flats mostly along tidal creeks. Two mangrove areas are seen near Mundra Port and one near the Navinal coast.

\section{$3 \quad$ Landforms of Erosional Coast}

The printing area is $159 \mathrm{~mm} \times 233 \mathrm{~mm}$. The text should be justified to occupy the full line width, so that the right margin is not ragged, with words hyphenated as appropriate. Please fill pages so that the length of the text is no less than $220 \mathrm{~mm}$, if possible.

\subsection{Wave Cut Platform}

A wave-cut platform, or shore platform is the narrow flat area often found at the base of a sea cliff or along the shoreline of a sea that was created by the action of waves. Wave-cut platforms are often most obvious at low tide when they become visible as huge areas of flat rock. Sometimes the landward side of the platform is covered by sand, forming the beach, and then the platform can only be identified at low tides or when storms move the sand. Material produced due to erosion of wave cut platform may be deposited at the end of the platform, forming an off-shore terrace.

Such wave cut platform occurs on Modava spit in between Mandvi and Mundra (Plate 3b, d). Or we can say that due to presence of hard rocks of Tertiary age in the offshore intertidal zone, Modava spit has been formed.

\section{Coastal Dynamics and Neotectonic}

Coastal environments are among the most dynamic on the earth's surface, and there are several facets to 'change'. At the outset, it must be emphasized that many coastal changes are circulatory in space or periodic in time. The idea of change is not a new one in coastal studies. Descriptions of coastal changes date from the Middle Ages, especially in the context of harbour silting and seafood harvests. What is new is a realization that these changes may be linked, perhaps via tortuous pathways. For coastal geomorphologist, many of the best clues come from geologists, meteorologists and biologists. In recent years, all these disciplines have undergone a revolution in approach, with greater emphasis being placed on dynamic processes rather than static descriptions. The information technology and data acquisition and handling methods is beginning to have a profound effect on the field sciences, coastal studies included which has also helped this study a lot.

According to one principle of classification, an emergent coastline is a coastline which has experienced a fall in sea level, because of either a global sea level change, or local uplift. Emergent coastlines are identifiable by the coastal landforms, which are above the high tide mark, such as raised beaches. Alternatively, a submerge coastline is a coastline which has experienced a rise in sea level, due to a global sea level change, local subsidence, or isostatic rebound. Submerge coastlines are identifiable by their submerged, or 'drowned' landforms.

\subsection{Coastal Dynamics and Neotectonic of Mandvi to Mundra Coast}

The landscape of Kachchh is very significantly influenced by structural pattern within it. The present geomorphic configuration of the Kachchh basin is the result of post-Mesozoic differential uplift along various intra-basinal faults, which are also responsible for recurrent seismic activity in the region [3][5]. 

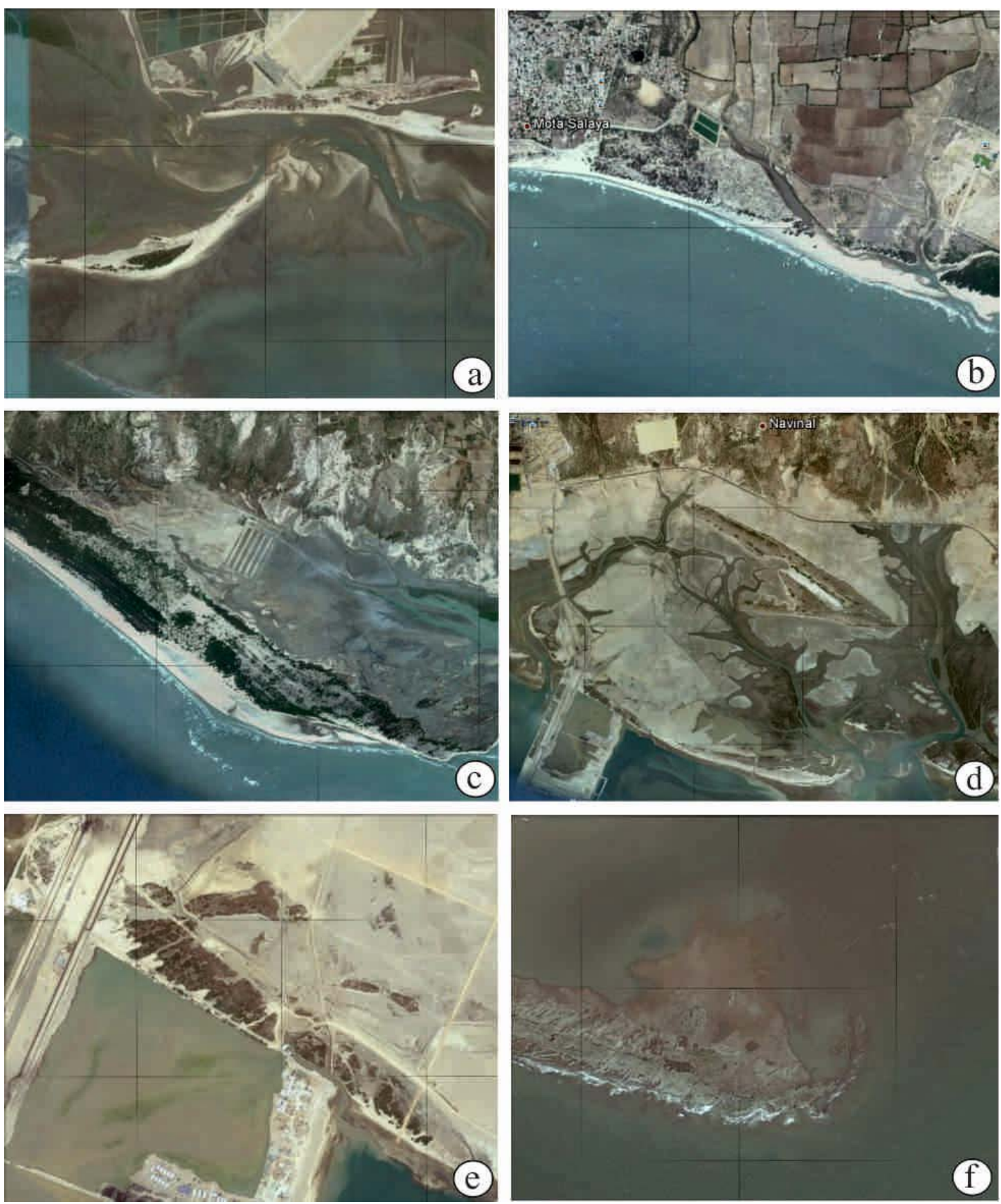

Plate 1. Mandvi to Mundra segment (a). Barrier islands and saltpan. (b). Beach, dune, creek, tidal flat and ridgerunnel on beach. (c). Modava spit, beach-ridge-runnel, raised beach, sand dunes, tidal flats, creeks, saltpan and guard-rock exposures on tip. (d). Mundra dune, Kodaki and Bharadimata creeks, tidal flats, hooked barrier, bar, Phot delta on Navinal coast. (e). Parabolic dunes, New Mundra Port and tidal flats. (f). Rocky exposure and origin of spit-bar-barrier. (Modified after Google Earth).

According to [1] the pattern was produced by primordial fault pattern in the Pre-Cambrian basement. Major uplifts took place several times since then, especially along a series of first order E-W lineaments and have led to differential movements of discrete basement blocks and consequent drape-folding of the blanketing sediments, while some of the folds are attributable to syn-tectonic plutonic intrusions [1]. In the Kachchh mainland, bordering the Arabian Sea consists mostly of hill ranges, uplands and shallow colluvial plains. Unidirectional movements since the late Cretaceous have not only resulted in a youthful 
topography, but also accentuated the structural pattern. Each uplifted segment is generally bounded by a fault or sharp monoclinal flexures along its northern edge at a gentle dip slope in the south, creating in the process typical cuesta topography. Movements along N-S structural high in the basement that cut across the E-W structural trend and is called median high considerably influenced the structure, facies and sediment thickness to the east and west of it [4], which also influences coastal geomorphology much more and inscribed its signature on coastal features.
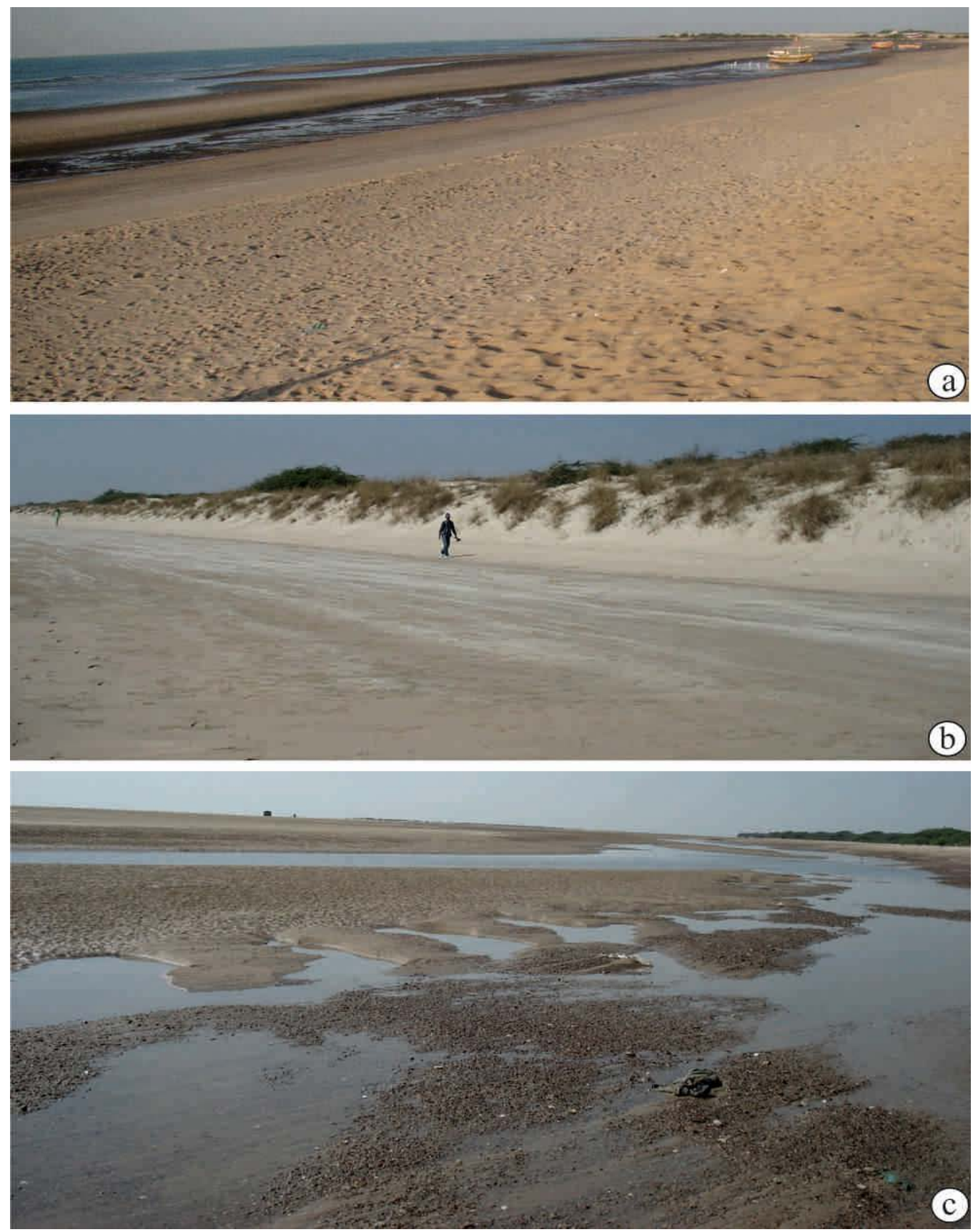

Plate 2. Mandvi to Mundra segment (a). Ridge and runnel system. (b). Coastal dunes and tidal flat. (c). Beach, ridge-runnel with antidunes. 
It also appears to have influenced the broad morphological pattern on both its sides including coast, acting as a hinge zone and uplifting the eastern part of the basin and simultaneously down tilting the western part $[1][2]$.
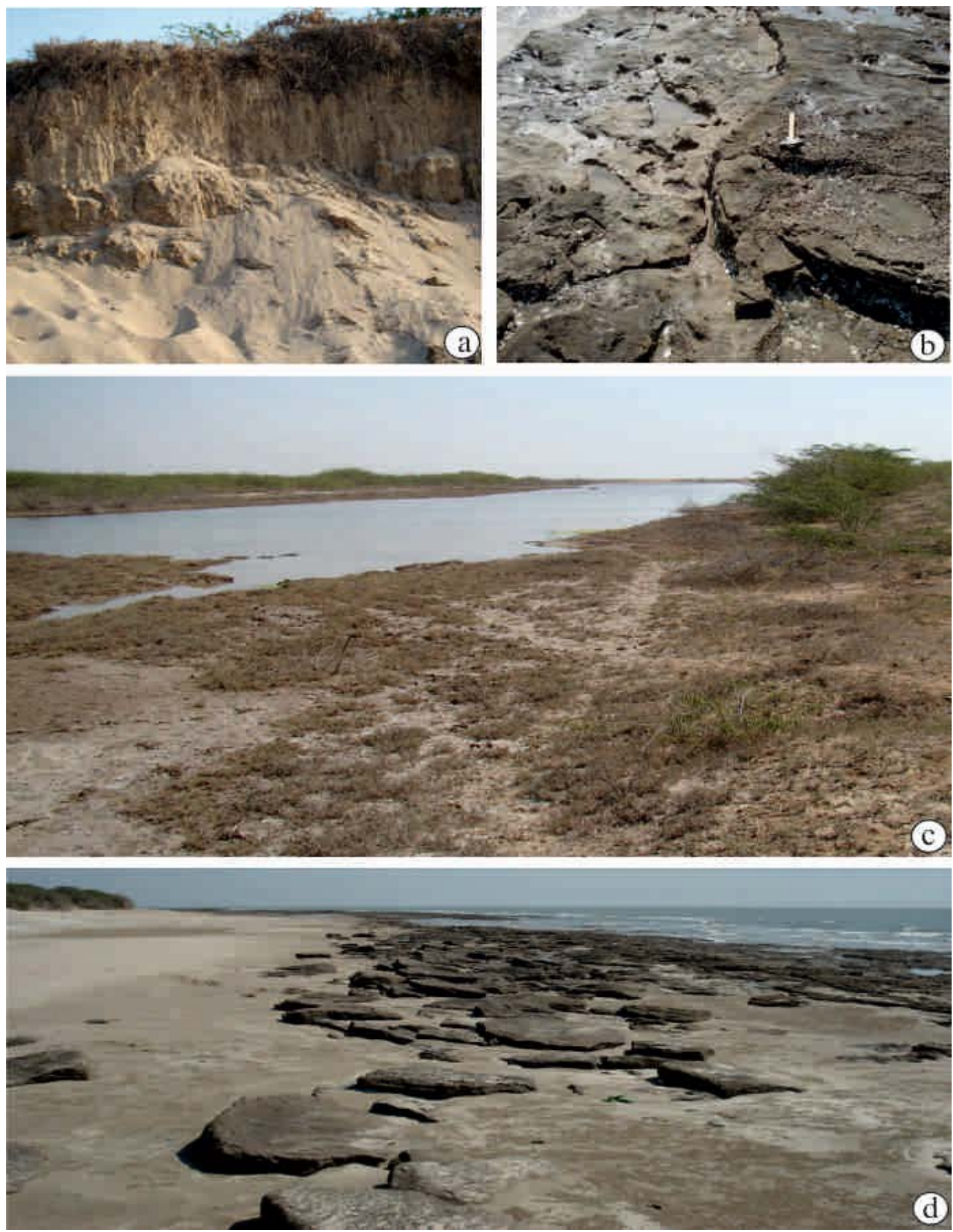

Plate 3. Mandvi to Mundra segment (a). Raised beach. (b). Displacement along fractures at Modava spit showing tectonic activity. (c). Tidal creek behind Modava Spit. (d). Exposures of hard rock (wave cut platform) and tidal flat at Modava spit.

A set of three fluvial terraces along many streams in the mainland, incised stream channels and recent gullies along the margin of Great Rann of Kachchh in the north and the Little Rann in the east suggest the tectonic movements have taken place in the Quaternary period to the present [2][12]. A part of 
Great Rann was uplifted by about $3 \mathrm{~m}$ during the major earthquake in 1819 . With such scenario it is conceivable that the coast line of Kachchh was also influenced by the regional tectonic activities. The coastal landforms of the area comprise an interesting assemblage of palaeo- as well as present-day coastal landforms. The geomorphic diversity with features indicating submergence as well as emergence suggests a complicated geomorphic history, which is not yet known [14].

The last climatic shift to aridity plus neotectonism especially along the major E-W lineaments affected the drainage greatly [1][12]. The delta was truncated and tilted with a southward dip, causing it to be partially submerged. In fact, with each episode of movement during the Quarternary, the major EW lineament - controlled blocks were uplifted along their northern margin and tilted southward [2]. Due to which, the coast line is expected to become more wave dominated [14].

The coastal alluvial plain was formed by deposition of fluvial sediments over the peneplained Tertiary rocks during upper late Pleistocene in two separate tectonically created basins. The sea level was higher than present during 6-2 ka [15]. Emergent coastal features consisting of raised beaches, raised mudflats, abandoned coastal cliffs, uplifted estuarine tidal to fluvial terraces, and stabilized coastal dunes developed because of uplift during the last $2 \mathrm{ka}$. The various morphotectonic divisions of the coast are attributed to the role played by the inherent structural fabric, the subsurface Median high and general uplift of the coast due to tectonic activity along the E-W trending faults to the north of the study area during the early Holocene and the last $2 \mathrm{ka}$. The semi-arcuate shape of the coastline in this part mimics the dip pattern of the Tertiary rocks [15].

Rates of aseismic or coseismic uplifts, styles and patterns of Quaternary deformation, and seismicity have also been determined from coastal geomorphic studies [20]. Gradual reduction in the ruggedness of the topography toward south, the southward tilt of the Cenozoic erosional surfaces, and southward dips of the Mesozoic and Tertiary rocks indicate that southern mainland Kachchh represents a large tilt block [2][19] delimited by the Katrol Hill Fault in the north and the Gulf of Kachchh Fault in the south.

The changes in the coastal morphology depend on a number of factors such as erosion and deposition due to climatic variations; local and regional tectonic setting and structural controls including upheaval and subsidence, faulting and folding of the area, lithology of the coastal zones, etc. as well as sea level dynamics - transgression and regression.

Details regarding all such aspects related to various segments of the study area have been discussed in the following paragraphs based on geomorphic features occurring in Mandvi to Mundra segment.

\subsubsection{Mandvi to Mundra (Spits and Cuspate Foreland Complex) Segment}

The Mandvi-Mundra segment is on the margin of the Gulf of Kachchh and Arabian Sea. It displays a distinctly different geomorphic setup with other coastal segments. Erosion of coastal alluvial plain has given undulating eroding-subsiding coast. The main distinguishing characteristics of the segment are wavy coastline, wide tidal-flat zone with extensive mangroves and domination of depositional landforms like spits and bars, and a well-developed coastal alluvial plain. In the segment a well-developed coastal alluvial plain comprising late Quaternary sediments is present towards land from the coastline.

The segment is characterized by coastal geomorphic features like beaches (ridge and runnel), raised beaches, coastal dunes, fore-dunes, parabolic dune remnants and Mundra dune- a stabilized or palaeofore-dune, tidal flat, raised tidal flat, backwater, creek, lagoon, spit, bar, river estuary, mangrove, firm sub-tidal mud pockets on beach and delta. This segment is quite interesting.

When sea level was high 2000 years BP [9] erosion of coastal alluvial plain in this segment has produced more or less straight to concave coast-line due to encroachment of sea on soft substrate, on which Rukmavati (W), Khari (W), the Nagwanti, the Phot, and the Bhukhi river delta formation has occurred during early elevation phase of late Holocene. Present day major tidal creeks like Kotadi creek (two channels) and Bharadi mata creek are reaching out from the sea up to this palaeo-delta forming recent extended estuaries on this mixed wave cum tide dominated coast. The delta formation on the segment is comparable with early phase of late Holocene upheaval [15] and resulting rejuvenation of the fluvial system. The delta sediment is superimposed by tidal flat sediments deposited later during uplift in last 2000 years. Raise-beach, raise-tidal flat, firm sub-tidal mud pockets on beach, delta and parabolic dune remnants and palaeo-fore dune (Mundra dune) - all these features projects 3 to $4 \mathrm{~m}$ high palaeosea level than the present day. All these features are superimposed by present day active beach, dune, tidal flat, creek, spit, bar, lagoon, estuary and mangroves. 
Cuspate foreland topography is absent on the beach, which is replaced by ridge-runnel system that suggests shift in the coastal process from complete dominance of wave to partial dominance of waves along with tidal currents and long shore drift as in the case of Kanthada-Mandvi sub-segment. Small estuaries and spits with landward curve show energetic wave action. Spit with seaward curves indicates rejuvenation of fluvial system and uplift of the segment during recent times.

Origin of Modwa spit is proposed by [14] in following way. The NW-SE oriented straight coastal outline of Jakhau-Mandvi segment takes an eastward turn of $23^{\circ}$ in this coastal segment. As a result the waves, normal to the straight coast segment impinge against the bent coast line at an angle. This factor along with strong eastward long shore drift helps in gradual development and subsequent decay of a number of spits from the headland, while wave refraction at the tip of the spit produces complex recurvatures. The cycle of development of every individual spit is completed with severance of its connection with the mainland in the west, followed by an erosional cuspate form development. In other words, as the fulcrum is shifting over time there is erosion at the proximal, western end of the spit and concurrent deposition in the distal, eastern end [14]. The best example is Rawal Pir-Modwa Spit, whose western end near Rawal Pir is now under erosional phase, while a new spit is gradually emerging at Modwa. The present fulcrum of the spit lies at Modwa. The alignment of the older spit remnants is intersected by that of the newer shore lines at an angle of about $45^{\circ}$ or more.

Present study reveals that presence of hard rocky platform and protection against erosion provided by it on tip of Modwa spit is responsible for the creation of spit by combined action of wave and tide related long shore current deposition. Extension of same rocky platform in $\mathrm{N} 73^{\circ} \mathrm{W}-\mathrm{S} 73^{\circ} \mathrm{E}$ direction beyond tip of Modwa spit has resulted in to sinuous hook and deposition on the backside lagoon.

The $3 \mathrm{~m}$ high raised beach may provide some important clues to the recent morphological history of its erosional segment [14]. There is not enough evidence to suggest that the raised beach is related to the eustatic change of the base level. The mud flat coast to its east is associated with the uplifted eastern part of the mainland [14].

Present study [15] provides enough evidence that the entire Kachchh coast is tectonically uplifted since last 2000 years. The upheaval is still continuous.

The dunes are partially stabilized on the landward side [15]. Present study reveals that the fore-dunes on the Modwa spit and Navinal fore-dune covers stabilised parabolic dunes related to high sea level of the past. Raised beaches also occur right from Kashi Vishwanath (east) coast of Mandvi, Modwa spit up to Navinal beach where middle part of Navinal beach also contains raised tidal flats and sub-tidal mud pockets. Deltas of Rukmavati (W), Khari (W), the Nagwanti, the Phot, and the Bhukhi, enter the sea along this segment which is completely covered by tidal flats towards the coast. Creeks are mostly extending up to outer reaches of the deltas within tidal flats. A well-developed Modwa spit is present to the east of Mandvi. Overall, the segment shows active aggradations as the dominant process. However, the sediments become progressively finer toward the east as evidenced by the replacement of sandy beaches with tidal flats. Raised beaches and raised tidal flats are also common all along the coast from Mandvi to Mundra forming 2-4 m high cliffs. Tidal flats and mangroves are increasing from west to east. Development of vast tidal flats, occurrence of dead mangrove stumps, abandonment of old Mundra port, Mundra port and construction of new Mundra port south of Navinal village in between Kotadi creek in 2010 towards west clearly indicates upheaval of entire area in recent past (Fig. 3). Similar observations are made by [15] on the coast.

Another interesting feature is presence of Mundra dune towards south of Navinal village, on which Bharadi mata temple is situated. The dune shows multiple developmental phases from north to south as fore-dune. The first phase of dune development occurs on north which is oriented in $\mathrm{N} 60^{\circ} \mathrm{W}-\mathrm{S} 60^{\circ} \mathrm{E}$ direction (Fig. 2). It is superimposed by second phase in the middle part in $\mathrm{N} 53^{\circ} \mathrm{W}-\mathrm{S} 53^{\circ} \mathrm{E}$ orientation. Third and fourth phase occur towards SW in form of small extension oriented in $\mathrm{N} 58^{\circ} \mathrm{W}-\mathrm{S} 58^{\circ} \mathrm{E}$ and $\mathrm{N} 66^{\circ} \mathrm{W}-\mathrm{S} 66^{\circ} \mathrm{E}$ respectively. It is followed by rotation of beach by wave and tide action where orientation of fifth dune phase is in $\mathrm{N} 81^{\circ} \mathrm{E}-\mathrm{S} 81^{\circ} \mathrm{W}$. Last major phase is visible as $\mathrm{N} 82^{\circ} \mathrm{W}-\mathrm{S} 82^{\circ} \mathrm{E}$ oriented southern ridge. The dune is situated at central part of Navinal tidal flats in horizontal ' $V$ ' or spatulate form. It shows first place of barrier beach formation on landward side of which lagoon must be filled up to form tidal flats. Beach remnants are found on frontal tidal flat to this dune in form of coarse fossiliferous sand in a stretch of $450 \mathrm{~m}$ wide and $900 \mathrm{~m}$ long pocket in between Kotadi and Bharadi mata creeks. Present day length of north limb of the dune is $5 \mathrm{~km}$, while south limb is $3.5 \mathrm{~km}$. Approximately $2.5 \mathrm{~km}$ south of ancient remnant of beach-dune complex; present day active beach dune complex is formed with 2 
parallel dunal ridges. Length of the recent beach with raised beach is $\sim 7 \mathrm{~km}$. The lagoon in between first and second phase of beach-dune complex must have been filled later on to give rise to tidal flats. All such characters are indicative of continual upheaval of the coast since last 2000 years. Exact dates of different phases of upheaval are required for in depth study.

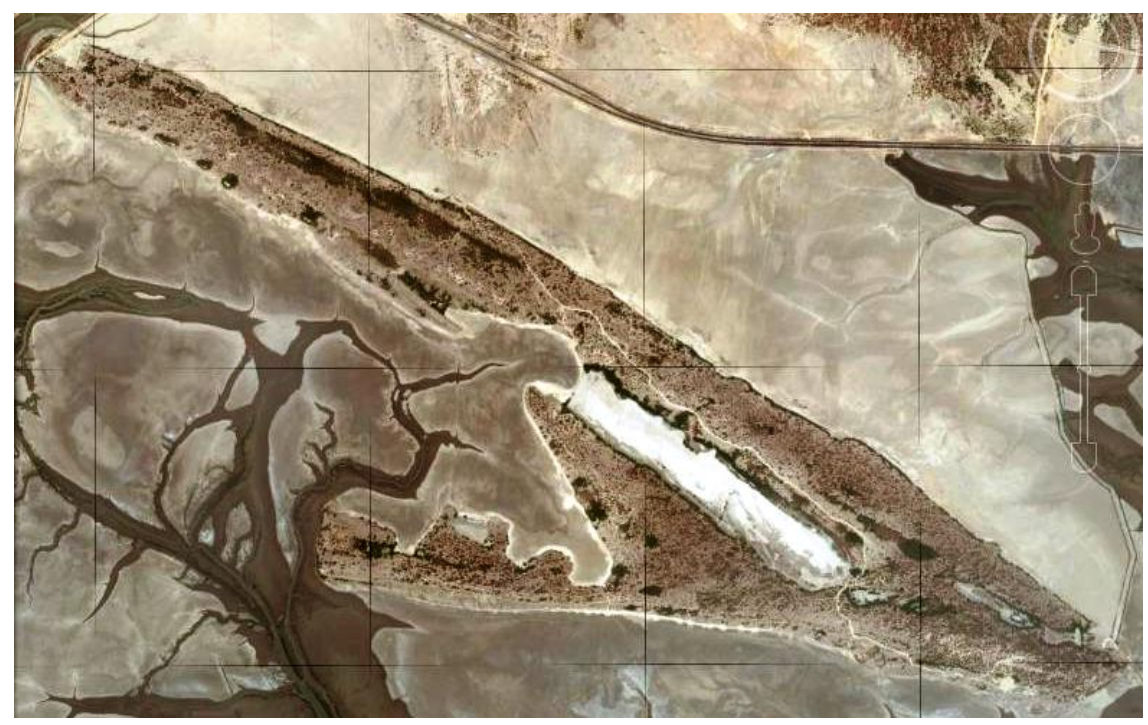

Figure 2. Phases of development of Mundra dune along Navinal coast in Mandvi-Mundra segment.

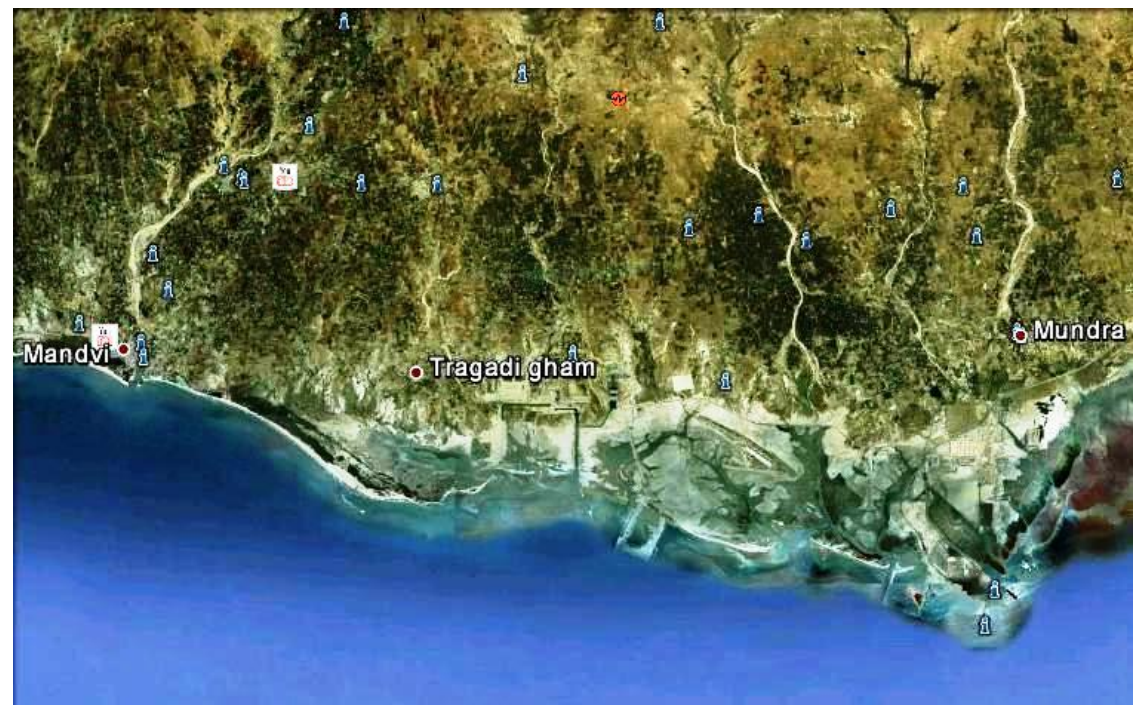

Figure 3. Sketch map showing lineament and structural control on the development of coast on Mandvi to Mundra Segment (modified after Google Earth).

\section{$5 \quad$ Inferences on Coastal Dynamics}

In the Kachchh palaeo-rift basin, a major part of the Quaternary period is identified as a period of tectonically controlled regional-scale peneplanation of the Mesozoic and Tertiary rocks [15]. This peneplained surface designated as the early Quaternary surface [2] is expressed by him as a southerly to south-westerly sloping bevelled surface developed over the late Tertiary rocks. As per [15], neotectonic 
activity along the N-S trend during the early part of late Pleistocene created depositional basins on either sides of the Median high and initiated the tectonic segmentation of the coastal zones as observed at the present day. They have also indicated deep incised late Pleistocene fluvial sediment succession and phase of severe erosion during early Holocene that was aided by tectonic uplift of the coastal zone.

Present study has revealed that all the coastal segments show features of emergence in response to tectonic uplift during the last 2000 years even though the coastline of Kachchh displays varying geomorphic characteristics and landform assemblages. The active coastline comprising mudflats, beaches, spits, and bars and coastal dunes appears to be the product of the coastal processes operating since the last 2000 years. The various morpho-tectonic divisions of the coast indicate a significant role played by transverse tectonic trends, the Median high and tectonic tilting due to movements along E-W trending faults to the north in the late Quaternary geomorphic evolution of the Kachchh coast [2]. Present day geomorphic features are superimposed on geomorphic features of mid- to early Holocene. Kachchh coast is a compound coast, where cliffs, estuaries, inlets etc. represent submergence, while barriers, coastal dunes etc. suggest emergence.

\section{Discussion}

The Kachchh coastline shows a macro-tidal environment and is characterized by mainly sand composed geomorphic landforms. The main source of fine grained sediment in the Gulf is river Indus situated 100 $\mathrm{km}$ northwest [8][13]. Based upon physiography it has been deduced that the entire inner shelf of the Arabian Sea between the mouth of river Indus to the Gulf of Kachchh is influenced by fluvial influx of river Indus, which is inhibited from further southward transportation due to a strong tidal barrier off the mouth of the Gulf of Kachchh [6][7]. The future scenario for the Indus-Saraswati delta has been sketched by [18] as straightening of the coast line, transgression of the delta-front sands and gradual dominations of aeolian activity due to loss of vegetation.

The various morpho-tectonic divisions of the coast indicate a significant role played by transverse tectonic trends, the Median high and tectonic tilting due to movements along $\mathrm{E}-\mathrm{W}$ trending faults to the north in the late Quaternary geomorphic evolution of the Kachchh coast [2].

The landscape of Kachchh is very significantly influenced by structural pattern within it. The present geomorphic configuration of the Kachchh basin is the result of post-Mesozoic differential uplift along various intra-basinal faults. Gradual reduction in the ruggedness of the topography toward south, the southward tilt of the Cenozoic erosional surfaces, and southward dips of the Mesozoic and Tertiary rocks indicate that southern mainland Kachchh represents a large tilt block [2][19] delimited by the Katrol Hill Fault in the north and the Gulf of Kachchh Fault in the south.

[11] suggest a complex interaction between tectonics and sea-level variations. The oldest age of 14.3 ka of carbonate (dolomite crust), occurring at $35 \mathrm{~m}$ in the Gulf of Kachchh [11], indicates that the sea had transgressed into the gulf at least by $\sim 15$ ka. Moreover, corals occurring at $28 \mathrm{~m}$ depth and dated to $10.8 \mathrm{ka}$ when compared with the global sea level of $\sim 70 \mathrm{~m}$ at $11 \mathrm{ka}[10]$ suggest tectonic uplift by $\sim 40 \mathrm{~m}$ during the Holocene [11]. [15] inferred that a major part of this uplift occurred during the early Holocene, which resulted in extensive fluvial erosion and incision of the upper late Pleistocene sediments of the coastal alluvial plain. All these movements of the Kachchh block have played significant roles in the outline of present day geomorphology of coast.

The occurrences of raised mudflats, raised beaches, stabilized coastal dunes, and abandoned rocky cliffs suggest that the sea level was higher than present from 6 to $2 \mathrm{ka}$ [15], which can be attributed to the relatively stable sea level during mid-late Holocene. The presence of coastal deposits well above the present sea level suggests emergence of the coast in response to tectonic uplift which is still continuous during the last $2 \mathrm{ka}$, which formed the present geomorphic setup of the coastal zone of mainland Kachchh.

The mudflats are silt and clay dominated landform that gradually becomes clay rich eastwards. The mudflats receive suspended sediments at slow but steady pace, which are not eroded after deposition due to their cohesive nature and currents of lower energy [17].

The changes in the coastal morphology depends on number of factors such as erosion and deposition due to climatic variations; local and regional tectonic setting and structural controls including upheaval 
and subsidence, faulting and folding of the area, lithology of the coastal zones, etc. as well as sea level dynamics - transgression and regression.

Kachchh coast line mainly shows landforms of depositional coast at present such as inshore crescentic barrier beaches, fore dunes, tidal creek, tidal mud flat, parabolic dunes, lagoons, saline sand flats, mangroves, river delta, beaches (ridge and runnel), coastal dunes, bar, spit, river estuary, saltpan and landforms of erosional coast such as sea cliffs and wave cut platforms of the past ages covered partially under or tapered against present day depositional forms. The forms have been studied in the field wherever it was possible and checked with the help of satellite images available on Google Earth.

\section{Conclusion}

The following broad conclusions could be arrived at from the above accounts.

The segment Mandvi to Mundra with their hinterland in the Kachchh mainland, receive less fluvial sediments and are comparatively narrow.

Emergent coastal features consisting of raised beaches, raised mudflats, uplifted estuarine, tidal to fluvial terraces, and stabilized coastal dunes developed because of uplift during the last 2 ka.

The conclusion of the segment is described below.

\subsection{Mandvi to Mundra Segment}

Mandvi to Mundra segment is mainly represented by spit and cuspate foreland complex indicating dominance of complex depositional and erosional processes on an emerging coast line. This segment shows both coarse as well as fine sediments. The geomorphic assemblage indicates that this coast acts as a transition zone between the sand rich coast in the west and the mud rich coast towards the east.

Present day major tidal creeks like Kotadi creek (two channels) and Bharadimata creek are reaching out from the sea up to this palaeo-delta forming recent extended estuaries on this mixed wave cum tide dominated coast. The delta formation on the segment is comparable with early phase of late Holocene upheaval [15] and resulting rejuvenation of the fluvial system. The delta sediment is superimposed by tidal flat sediments deposited later during uplift in last 2000 years. Raise-beach, raise-tidal flat, firm sub-tidal mud pockets on beach, delta and parabolic dune remnants and palaeo-fore dune (Mundra dune) - all these features projects 3 to $4 \mathrm{~m}$ high palaeo-sea level than the present day. All these features are superimposed by present day active beach, dune, tidal flat, creek, spit, bar, lagoon, estuary and mangroves.

The best example is Rawal Pir-Modwa Spit, whose western end near Rawal Pir is now under erosional phase, while a new spit is gradually emerging at Modwa. The present fulcrum of the spit lies at Modwa. The alignment of the older spit remnants is intersected by that of the newer shore lines at an angle of about $45^{\circ}$ or more. Present study reveals that the presence of hard rocky platform and protection against erosion provided by it on tip of Modwa spit is responsible for the creation of spit by combined action of wave and tide related long shore current deposition. Extension of same rocky platform in $\mathrm{N} 73^{\circ} \mathrm{W}-\mathrm{S} 73^{\circ} \mathrm{E}$ direction beyond tip of Modwa spit has resulted in to sinuous hook and deposition on the backside lagoon.

Another interesting feature is presence of Mundra dune towards south of Navinal village, on which Bharadimata temple is situated. The dune shows multiple developmental phases from north to south as fore-dune indicative of continual upheaval of the coast since last 2000 years. Exact dates of different phases of upheaval are required for in-depth study.

The dunes are partially stabilized on the landward side [15]. Present study reveals that the fore-dunes on the Modwa spit and Navinal covers stabilized parabolic dunes related to high sea level of the past.

Overall, this segment shows active aggradations as the dominant process. However, the sediments become progressively finer toward the east as evidenced by the replacement of sandy beaches with tidal flats. Raised beaches and raised tidal flats are also common all along the coast from Mandvi to Mundra forming 2-4 m high cliffs. Tidal flats and mangroves are increasing from west to east. Development of vast tidal flats, occurrence of dead mangrove stumps, abandonment of old Mundra port, and construction of new Mundra port south of Navinal village in between two Kotadi creeks in 2010 towards west clearly indicates upheaval of entire area in recent past. 


\section{References}

1. S. K. Biswas, "Note on the Geology of Kutch," Quarterly Journal of the Geological, Mining and Metallurgical Society of India, vol. 43, no. 4, pp. 223-236. 1971.

2. S. K. Biswas, "Landscape of Kutch," A Morphotectonic Analysis, Indian Journal of Earth Sciences, vol. 1, no. 2, pp. 177-190.1974.

3. S. K. Biswas, "Regional tectonic framework, structure and evolution of the western marginal basins of India". Tectonophysics, vol. 135, pp. 307-327.1987.

4. S. K. Biswas and S. V. Deshpande, "Geological and Tectonic maps of Kutch," Bull. O. N. G. C., vol. 7, no. 2, pp. 115-123. 1970.

5. S. K. Biswas and K N. Khattri "A geological study of earthquakes In Kutch, Gujarat," India Jour Geol Soc India, vol. 60 (2), pp. 131-142. 2002.

6. O.S. Chauhan, "Influence of macro tidal environment on shelf sedimentation, Gulf of Kachchh, India." Continental Shelf Research, 14 (13/14):1477-1493. 1994.

7. Onkar S. Chauhan, F. Almeida and Jangam Suneethi, "Influence of Sedimentation on the Geomorphology of the Northwestern Continental Margin of India". Marine Geodesy, vol. 23, pp.259-265, 2000.

8. O.S. Chauhan, S. Jayakumar, A.A.A. Menezes, A.S. Rajawat, and S. R. Nayak, "Anomalous inland influx of the River Indus, Gulf of Kachchh, India”, Mar. Geol., vol. 229 (1-2), 91-100, 2006. doi:10.1016/j.margeo.2005.12.003.

9. Avijit Gupta, Tropical Geomorphology, Cambridge University Press, 1975.

10. R. G. Fairbanks, "A 17,000 year glacio-eustatic sea level record: Influence of glacial melting rates on the Younger Dryas event and deep-ocean circulation." Nature, 342, pp. 637-642. 1989.

11. Purnachandra V. Rao; G. Rajagopalan; K.H. Vora and F. Almeida, 'Late Quarternary sea level and environmental changes from relic carbonate deposits of the western margin of India'. Proceedings of the Indian Academy of Science (Earth and Planetary Sciences), 112 (1), 1-25, 2003.

12. Amal Kar, "Kachchh, India: Evidence of physiographic evolution." Continental Shelf Research, 1988.

13. N. H. Hashimi, R. R. Nair, and R. M. Kidwai, "Sediments of the Gulf of Kachchh, A high energy tide dominated environment," Indian J. Mar. Sci., 71, pp.7. 1978.

14. Amal Kar, "Neotectonic Influence on morphological variation along the coastline of Kachchh, India." Elsevier Science Publisher, Amsterdam. pp. 199-219.1993.

15. D. M. Maurya, M. G. Thakkar, A. K. Patidar, S. Bhandari, B. Goyal and L. S. Chamyal "Late Quaternary geomorphic evolution of the coastal zone of Kachchh, western India," J. Coastal Res. 24 pp. 746-758. 2008.

16. National Wetland Atlas, Gujarat, Sponsored by Ministry of Environment and Forests, Government of India As a part of the project on National Wetland Inventory and Assessment (NWIA) Space Applications Centre (ISRO), Ahmedabad and Space Applications Centre (ISRO), Ahmedabad and Bhaskaracharya Institute for Space Applications and Geo-informatics (BISAG), Gandhinaga. Project Director: Dr. Sushma Panigrahy.2010.

17. S. P. Prizomwala, S. B. Shukla and N. Bhatt "Geomorphic Assemblage of the Gulf of Kachchh coast, Western India: Implication in understanding the pathways of Coastal sediments," Zeitshcrift Fur Geomorphology, v.54, 1, pp. 31-46. 2010.

18. J. T. Wells and J. M. Coleman, "Deltaic morphology and sedimentology with special reference to the Indus River Delta, Marine Geology and Oceanography of the Arabian Sea and Coastal Pakistan," New York: Van Nostrand Reinhold, pp. 85-100. 1984.

19. A. K. Patidar, D. M. Maurya M. G. Thakkar and L. S. Chamyal, "Fluvial geomorphology and neotectonic activity based on field and GPR data, Katrol Hill Range, Kachchh, Western India." Quaternary International 159: 74-92. 2007.

20. D.M. Maurya, M.G. Thakkar and L.S. Chamyal, "Quaternary Geology of the arid zones of Kachchh: Terra incognita." Proceedings Indian Nati. Sci. Aca. vol. 69, pp. 123-135, 2003. 